\title{
Fire-induced Mortality of Redberry Juniper [Juniperus pinchotii Sudw.]
}

\author{
ALLEN A. STEUTER AND CARLTON M. BRITTON
}

\begin{abstract}
Redberry juniper mortality was determined following spring broadcast burns in 1979 and 1980, and individual-plant burns with 3 heat treatments in 1981 . Mortality varied from 1 to $100 \%$ and was related to bud zone location, plant size, site, and growing conditions. During years of above average precipitation, mortality averaged $70 \%$ for plants with the bud zone above the soil surface contrasted to $3 \%$ for plants with the bud zone partially below the soil surface. Plant size and site factors such as slope and soll surface stability appeared to affect the rate at which the bud zone was buried by soil, thus producing a fire resistant plant. Plant mortality was significantly increased across all size classes and sites when burns were conducted under hotter conditions and followed by a dry growing season.
\end{abstract}

West Texas populations of redberry juniper (Juniperus pinchotii Sudw.) which were previously restricted to buttes and escarpments, appear to have expanded into grasslands since the 1860's (Ellis and Schuster 1968). Lack of periodic fire was thought to be partially responsible for this expansion. Wright (1978) estimated that grasslands in the Texas Rolling Plains had a natural fire frequency of 20 to 30 years.

The expansion of redberry juniper into grasslands may be due in part to relatively recent species adaptations to fire. Biogeographical and phenotypic evidence suggests that redberry juniper may be a stabilized hybrid of alligator juniper ( $J$. deppeana Steud., sprouter) and one-seeded juniper (J. monosperma Engelm., nonsprouter) (Hall and Carr 1968). Hybridization of redberry juniper and one-seeded juniper in northwest Texas has been supported using chemosystematic analysis (Adams 1972). However, no evidence of hybridization or introgression from other taxa was found (Adams 1975). Redberry juniper is least variable in the west Texas "arc" of its distribution. It is most variable in the Trans-Pecos where its range overlaps those of alligator and one-seeded juniper. Both Adams (1975) and Hall and Carr (1968) felt that redberry juniper experienced considerable change in distribution and natural selection during the late- and post-Pleistocene era.

Basal sprouting following top removal is an important phenotypic characteristic of redberry juniper (Vines 1960). Smith et al. (1975) reported $99 \%$ mortality of 1 - to 8 year-old redberry juniper after mechanical stem removal at the soil surface. Stem meristematic tissue was generally above the soil surface in this age class. However, with older trees soil typically covers the stem meristematic tissue. Seventeen percent of the mature redberry juniper failed to resprout following mechanical top removal (Schuster and George 1976). No information is available on redberry juniper mortality that may be expected following prescribed burning.

Redberry juniper is a major brush problem over extensive areas of north and west Texas. The objectives of this study was to

\footnotetext{
The authors are research assistant and associate professor, Department of Range The authors are research assistant and associate professor, Department of Range
and Wildlife Management, Texas Tech University, Lubbock 79409. A. Steuter's present address is The Nature Conservancy. Samuel Ordway, Jr. Memorial Prairie, Star Route 1, Leola, S. Dak. 57456. This study is a contribution of the College of Agricultural Sciences, Texas Tech University, No. T-9-293. We thank Bill Masterson and Frank Potts who let us conduct this study on their ranches.

Manuscript received May 20, 1982.
}

investigate the potential of prescribed burning for use in controlling redberry juniper.

\section{Methods}

The study was conducted on the Masterson Ranch, King County, and the Potts Ranch, Motley County, Texas. Redberry juniper-mixed grass vegetation is characteristic on both sites (Steuter 1982). Long-term (30 years) mean annual precipitation is $59 \mathrm{~cm}$ of which $90 \%$ occurs during the growing season. Soils on the King County area are shallow, rocky Mollisols of the Talpa series while those on the Motley County area are deep Alfisols of the Miles series.

Prior to broadcast burning an 800-ha pasture in 1979, 200 young redberry juniper plants were randomly selected and marked with a numbered metal stake. These young plants ranged from 7 to $65 \mathrm{~cm}$ tall. Fifty young plants were similarly marked prior to the 280 -ha broadcast burn in 1980 . These plants ranged from 16 to $80 \mathrm{~cm}$ tall. One hundred mature plants consisting of residual live stems and regrowth, as a result of chaining in 1975, were also monitored. A young plant was defined as being less than $80 \mathrm{~cm}$ tall and mature plants as greater than $1-\mathrm{m}$ tall.

Broadcast burns were conducted in mid-March with $25 \%$ relative humidity, air temperature from 20 to $26^{\circ} \mathrm{C}$, and windspeed from 12 to $24 \mathrm{~km} / \mathrm{hr}$. Fine fuel load ranged from 1,800 to 3,500 $\mathrm{kg} / \mathrm{ha}$. Depending on the treatment year, plant mortality was evaluated 6,18 , and 30 months after burning by examination for basal stem sprouts.

The second research phase involved burning redberry juniper plants with an individual plant burner (Britton and Wright 1979). One hundred and twenty plants were marked in each of 3 size classes ( 35 to 50,51 to 65,66 to $80 \mathrm{~cm}$ tall). Thirty plants within each size classes were randomly assigned to 1 of 4 treatments consisting of a control (no heat), light, moderate, and heavy fine fuel simulated fires. The plant burner was calibrated using the time/temperature curves developed for mixed grass fuels (Wright et al. 1976). The light, moderate, and heavy fuel ratings approximated natural fine fuel loads associated with redberry junipermixed grass habitats in west Texas (Fig. 1). Treatments were applied in early April with air temperatures from 20 to $26^{\circ} \mathrm{C}$ and relative humidity from 60 to $75 \%$. Plants were checked 5 months after treatment for evidence of living material.

The location of the swollen bud zone, relative to the soil surface, was recorded for plants in both broadcast and individual-burn treatments. Chi-square analyses were used to evaluate treatment differences at the $95 \%$ confidence level.

\section{Results and Discussion}

Mortality, across all size classes, of young redberry juniper broadcast burned in 1979 was $42 \%$ at the 6-month evaluation. The mortality in this same group of plants following the second, very dry growing season had increased to only $49 \%$. Thirty months after the fire, mortality was $50 \%$. These results indicate that the effects of disease, insects, and rodents will not interact with fire to appreciably increase the control of established redberry juniper. Mortality 


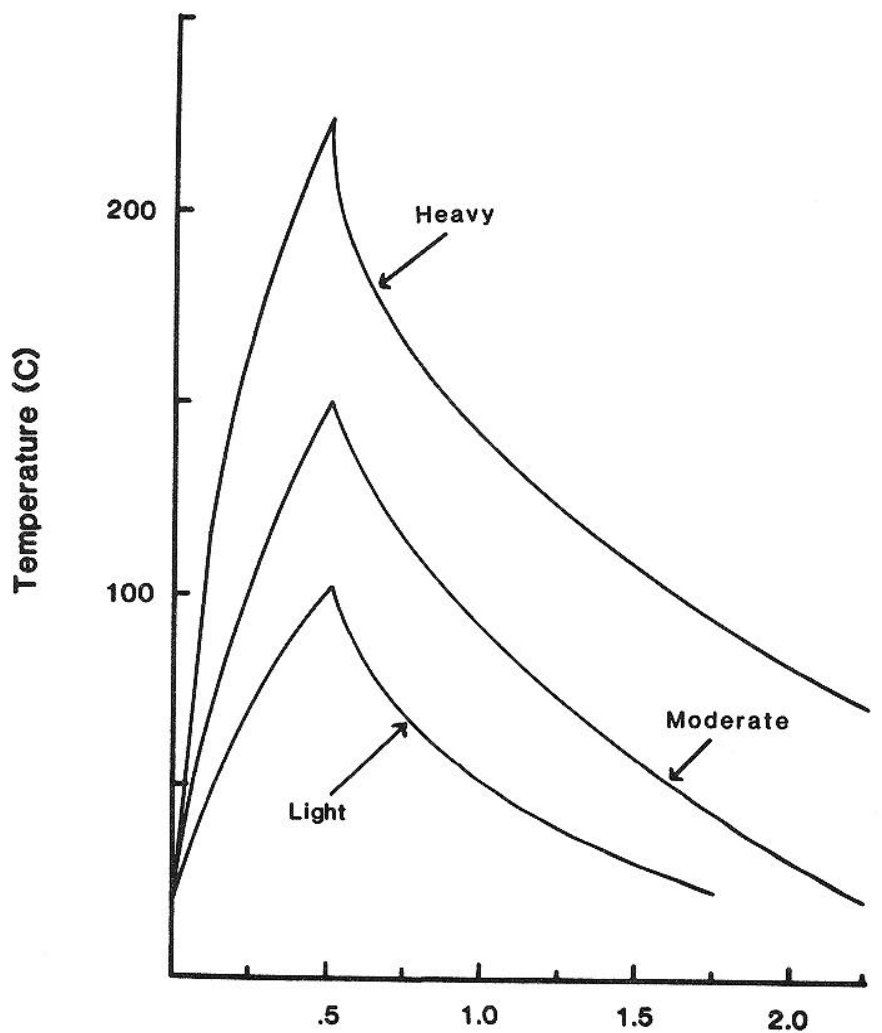

Time in Minutes

Fig. 1. Time-temperature curves used to simulate light, moderate, and heavy fine fuel loads with the individual plant burn treatments.

rates in following sections of this paper are from the evaluations conducted at the end of the first growing season after treatment ( 5 to 6 months).

A wide range in juniper mortality resulted from the broadcast and individual plant burn treatment groups (Fig. 2). Location of the bud zone relative to the soil surface was the dominant variable associated with mortality of redberry juniper plants subjected to fires within the range of mixed grass fuel loadings. Post-fire growing conditions also appeared to affect mortality following a prescribed burn.

\section{Bud Zone Location}

The bud zone of redberry juniper develops from stem meristematic tissue located in the axil of the cotyledons on a newly germinated seedling (Smith et al. 1975). This zone is from one to several centimeters above the soil surface (Fig. 3 ). The rate at which the bud zone is covered by soil and thus protected from a grassland fire appears to be determined by age, canopy development, slope, and soil surface stability. Dead foliage and airborn material fall through the juniper canopy and accumulate around the base. On shallow, sloping sites the rate at which this material accumulates will be reduced due to downslope transport of surface material. Mortality due to fire generally declined with increasing size of redberry juniper but appeared to be affected by site factors (Fig. 2).

Measurements taken from unburned plants indicated that young redberry juniper increased in height at the rate of approximately $3.8 \pm 2.2 \mathrm{~cm} / \mathrm{yr}$. Similar growth rates have been observed for other junipers (Tueller and Clark 1975). Within a site, juniper height may be a good indicator of bud zone location. However, bud zone location, not redberry juniper height or age, is the factor important in determining mortality rates following fire (Fig. 4).

The basal bud zone of mature redberry juniper is large, mostly buried, and safe from most fires. Only 1 of 100 marked plants was killed by broadcast burning in 1979. The bud zone of this plant had been mostly exposed by the chaining operation 4 years earlier.

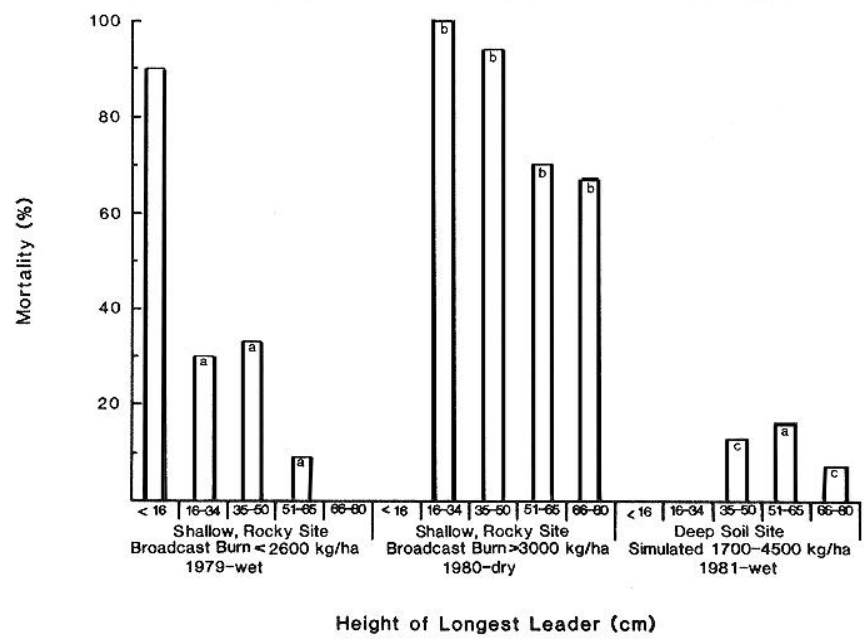

Fig. 2. Mortality by size class for young redberry juniper broadcast burned in 1979 and 1980 and individually burned in 1981. Letters within a size class that are the same represent no significant difference $(\mathrm{P}>0.05)$.

Burning in the drought year of 1980 killed approximately $5 \%$ of the mature plants. The plants that died typically had a large amount of woody debris from the chaining operation lodged around the base. Fire intensity in chained debris was considerably higher than for grassland fuels.

\section{Heat Treatment Effects}

Fire intensity $\left(\mathrm{kcal} / \mathrm{m}^{2} / \mathrm{sec}\right.$ ) is difficult to measure, much less simulate under field conditions. The individual plant burner accurately simulated time-temperature relationships to which a plant is exposed during a fire.

Redberry juniper mortality increased across size classes with increased heat treatment (Fig. 5). These results were supported by observations of increased mortality of large plants growing within locally heavy fine fuel accumulations in the 1979 and 1980 broadcast burns. Fires within the range typical of mixed grass fuel loads would rarely generate sufficient heat to kill redberry juniper bud zones below the soil surface. Fire prescriptions which allow for increased fine fuel accumulation and "hot" weather conditions will provide the best control of redberry juniper where the bud zone is above or at the soil surface.

\section{Growing Season Effects}

The growing conditions during 1979 and 1981 were good to excellent based on herbaceous production on the study area. Soils were moist at the time of burning and precipitation was $18 \%$ above the long-term average during the growing season. The soil was dry at the time of burning in 1980. Growing season precipitation $32 \%$

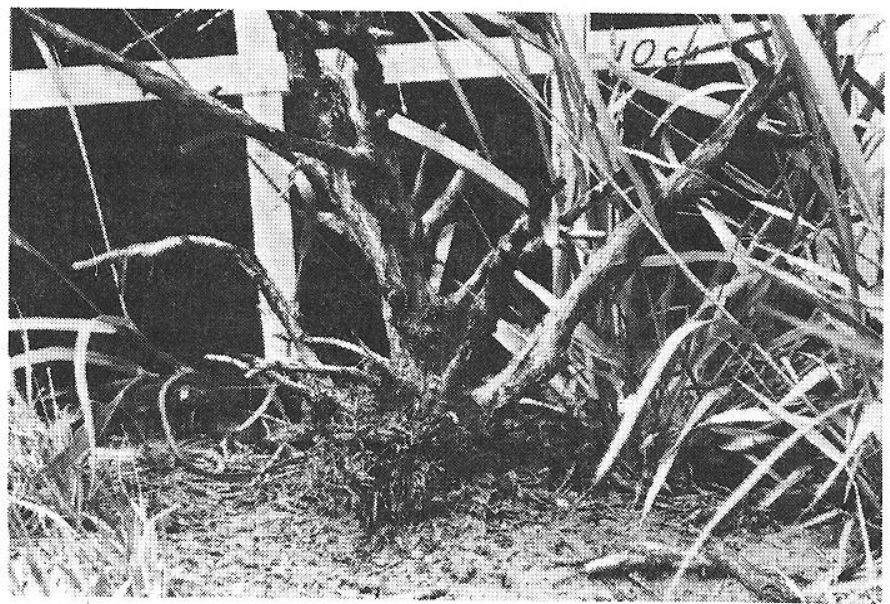

Fig. 3. Young redberry juniper with swollen bud zone near the soil surface at the time of a broadcast burn. 


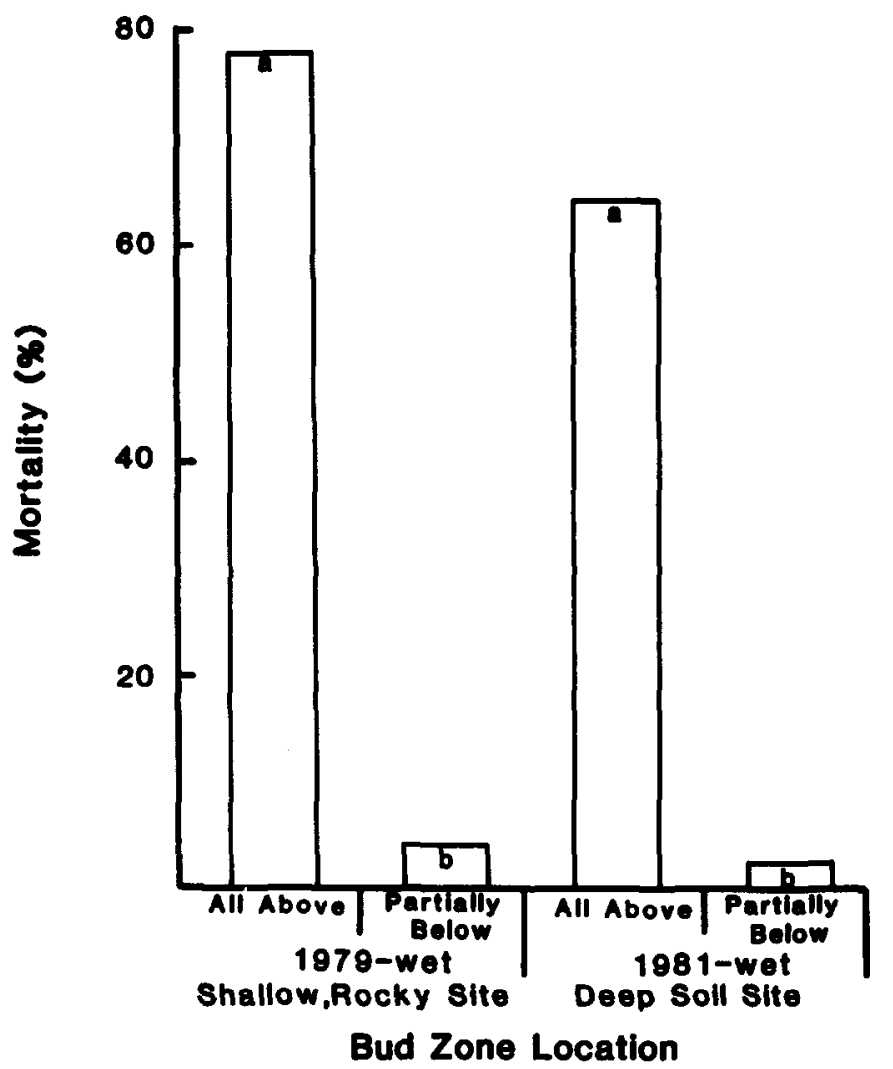

Fig. 4. Mortality rates for young redberry juniper from 7 to $80 \mathrm{~cm}$ tall and burning treatments (1979 and 1981) for plants with bud zones all above versus partially below the soil surface. Similar letters within bars represent no significant difference ( $\mathrm{P}>0.05$ ).

below average during 1980 combined with record setting summer temperatures to produce severe drought conditions on the study areas.

Redberry juniper mortality was increased even in the largest size classes following broadcast burning in 1980 (Fig. 2). A comparison of 1979 and 1980 mortality rates is confounded by greater fine fuel load in 1980 . However, the magnitude of difference between mortality in 1979 and 1981 (wet) versus 1980 (dry) indicates a response to growing season conditions independent of fuel load.

\section{Conclusions}

Prescribed burning can potentially kill a large proportion of young redberry juniper if the treatment is applied before the bud zone is partially covered by soil. On shallow rocky sites redberry juniper plants less than approximately 13 years old $(50 \mathrm{~cm})$ had mortality from 33 to $100 \%$ depending on size and growing season conditions. Soil covering of the bud zone may occur earlier on sites with deep soils, and gentle slopes. Mortality of plants with an estimated age of 10 to 13 years $(35$ to $50 \mathrm{~cm})$ on a deep soil site burned in a wet year was $13 \%$. Therefore, the interval between fires should be correspondingly shorter on these sites to obtain equivalent control of young redberry juniper. Mature redberry juniper resprouts following fire. However, about $5 \%$ of these plants are killed by fire during a dry year. Developing fine fuel loads of 3000 $\mathrm{kg} / \mathrm{ha}$ will appreciably improve the control obtained from burning redberry juniper, as will burning in a dry year. However, burning in a dry year will negatively affect herbaceous yield and chances of

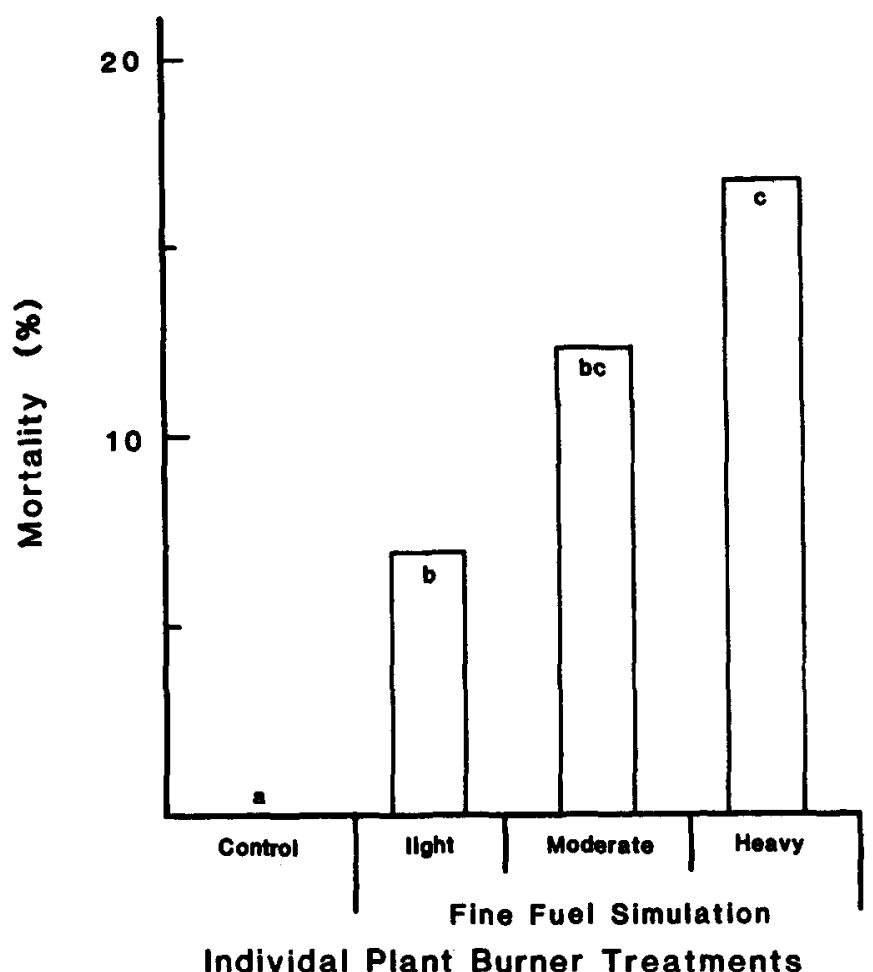

Fig. 5. Mortality for young redberry juniper from 35 to $80 \mathrm{~cm}$ tall for control, light, moderate, and heavy fine fuel simulation burns in 1981. Similar letters within bars represent no sigificant difference $(\mathrm{P}>0.05)$.

this should be minimized. Good soil moisture reserves at the time of burning are recommended to minimize the chances of reduced herbage yield.

\section{Literature Cited}

Adams, R.P. 1972. Chemosystematic and numerical studies of natural populations of Juniperus pinchotii, Sudu. Taxon 21:407-427.

Adams, R.P. 1975. Numerical-chemosystematic studies of intraspecific variation in Juniperus pinchotii. Biochem. Syst. and Ecol. 3:71-74.

Britton, C.M., and H.A. Wright. 1979. A portable burner for evaluating effects of fire on plants. J. Range Manage. 32:475-476.

Ellis, D., and J.L. Schuster. 1968. Juniper age and distribution on an isolated butte in Garza County, Texas. Southwest. Natur. 13:343-348.

Hall, M.T., and C.J. Carr. 1968. Variability in Juniperus in the Palo Duro Canyon of west Texas. Southwest. Natur. 13:75-98.

Schuster, J.L., and J. George. 1976. Redberry juniper response to top removal. J. Range Manage. 29:258-259.

Smith, M.A., H.A. Wright, and J.L. Schuster. 1975. Reproductive characteristics of redberry juniper. J. Range Manage. 28:126-128.

Steuter, A.A. 1982. Ecological role and potential use of fire in redberry juniper-mixed grass habitats. Ph.D. Diss. Texas Tech Univ., Lubbock.

Tueller, P.T., and J.E. Clark. 1975. Autecology of pinyon-juniper species of the Great Basin and Colorado Plateau, p. 27-40. In: The PinyonJuniper Ecosystem: A Symposium. Utah State Univ., Utah Agr. Exp. Sta., Logan.

Vines, R.A. 1960. Trees, shrubs and woody vines of the southwest. Univ. Texas Press, Austin.

Wright, H.A. 1978. Use of fire to manage grasslands of the Great Plains: Central and Southern Great Plains, p. 694-696. In: First Internat. Rangeland Congress Proc., Denver, Colo.

Wright, H.A., S.C. Bunting, and L.F. Neuenschwander. 1976. Effect of fire on honey mesquite. J. Range Manage. 29:467-471. 